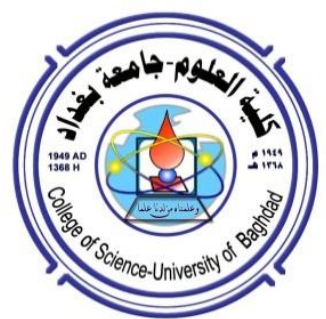

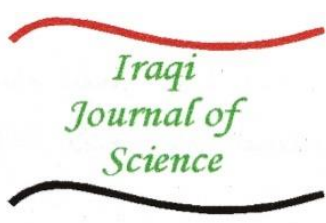

ISSN: 0067-2904

\title{
The effects of bio-fertilization and two levels of chemical fertilization on wheat (Triticum aestivum $\mathrm{L}$.) under drought conditions
}

\author{
Dina A. Saad ${ }^{1}$, Ayyad W. Al-Shahwany ${ }^{2}$, Hadi M. Aboud ${ }^{3}$ \\ ${ }^{1}$ College of Health and Medical Technology, Gilgamesh Ahliya University, Baghdad, Iraq \\ ${ }^{2}$ Department of Biology, College of Science, Baghdad University, Baghdad, Iraq \\ ${ }^{3}$ Directorate of Agriculture Research, Ministry of science and technology, Baghdad, Iraq
}

Received: 27/10/2020

Accepted: 23/12/2020

\begin{abstract}
A filed experiment was conducted to consider the impacts of bio-fertilizers (Azotobacter chroococcum and Glomus mosseae) and two levels of chemical fertilization ( $50 \%$ and $100 \%$ of recommended dose) on proline content and activities of antioxidant enzymes (catalase and peroxidase) in wheat Triticum aestivum L. cultivar IPA 99 under drought conditions (50\% and $20 \%$ of soil field capacity). Bio-fertilization involved treatment with A. chroococcum (Azoto) and $G$. mosseae (AMF), singly or in combination. The experiment was conducted by applying a Randomized Complete Block Design (RCBD) with three replications. The results of this study showed that the treatment utilizing Azoto+AMF fertilizer with concentrated chemical fertilizer (100\%) significantly decreased proline content and the activities of antioxidant enzymes under drought conditions. In addition, the percentage of mycorrihzal root infection was increased. The lowest values of proline content and catalase and peroxidase activities $(3.35 \mu \mathrm{mole} / \mathrm{g}, 84.52 \mathrm{unit} / \mathrm{ml}, 90.90$ unit/ml, respectively) were achieved by the application of combined bio-fertilizers with $100 \%$ of chemical fertilizer and $50 \%$ water deficit. The combined bio-fertilizer application with $50 \%$ of chemical fertilizer and $20 \%$ water deficit achieved the maximum mycorrihzal infection percentage $(90 \%)$.
\end{abstract}

Keywords: Antioxidant enzymes, Azotobacter sp., Bio-fertilizers, Glomus mosseae, Wheat, drought conditions.

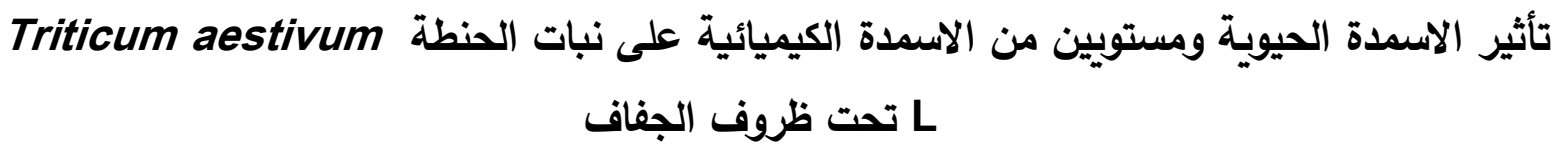

$$
\begin{aligned}
& \text { دينا عبد السلام سعد } 1 \text { ، أياد وجيه الثهواني ², هادي مهدي عبود3 } 3
\end{aligned}
$$

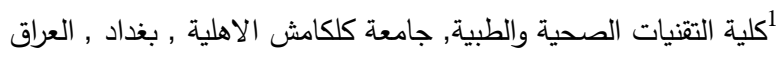

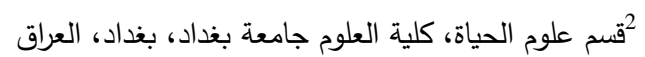

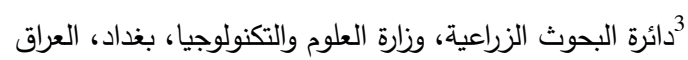

نفذت التجربة الحقلية لدراسة تأثير الأسمدة الحيوية Azotobacter chroococcum and Glomus)

mosseae)

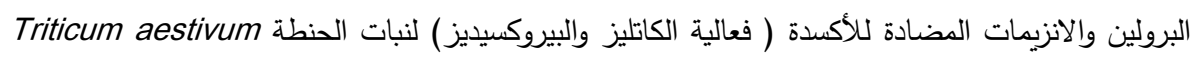

\footnotetext{
*Email: dinaabdalsalam@gmail.com
} 


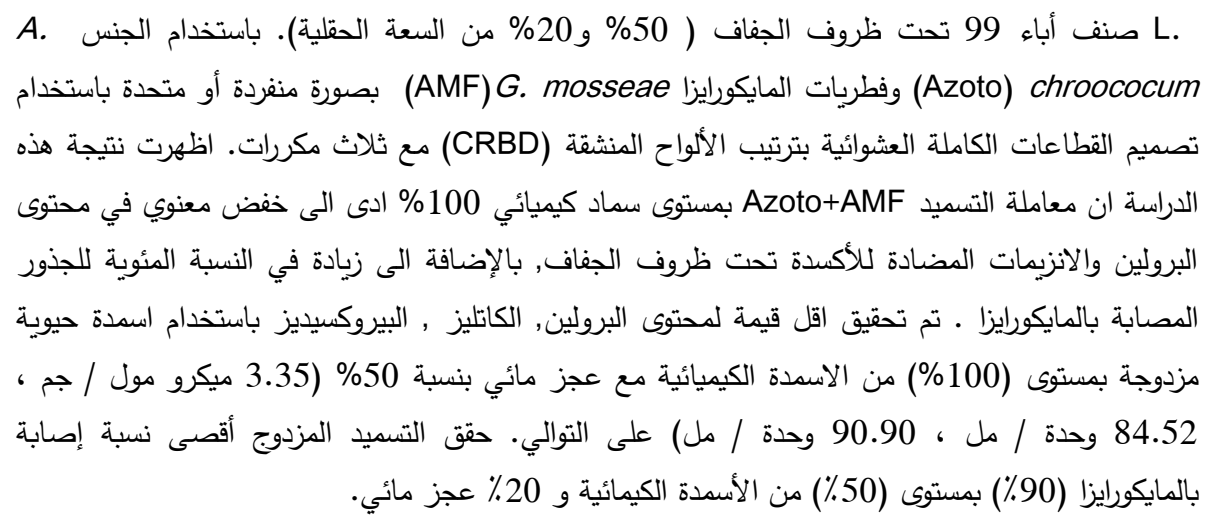

\section{Introduction}

Crop plants are vulnerable to various natural stresses, all of which influence plant growth and development, thus hampering crop efficiency [1]. Drought is considered to be the most destroying single natural stress, which, more than any other environmental stress, reduces crop productivity [2]. Drought influences morphological, physiological, biological, and molecular processes in plants, resulting in development restraint. Plants generally accumulate few types of compatible solutes such as proline, betaine, and polyols in the cytosol to elevate the osmotic pressure, thus maintaining both turgor and gradient-driven water absorption, and protect membranes and proteins [3]. In plant cells, the activity of antioxidant enzymes increases as a response to natural stresses. The development of Reactive Oxygen Species (ROSs) such as superoxide radical $\left(\mathrm{O}_{2}^{-}\right)$, hydrogen peroxide $\left(\mathrm{H}_{2} \mathrm{O}_{2}\right)$, hydroxyl radical $(\mathrm{OH})$, and singlet oxygen $\left({ }^{1} \mathrm{O}_{2}\right)$ can result from environmental stresses [4]. These ROSs can initiate destructive oxidative processes, including lipid oxidation, oxidation of proteins, and nucleic acids damage [5]. Plants exposed to stress from drought can overcome oxidative stress via the activation of some or all antioxidant enzymes [6,7].

Mycorrhizae is a mutualistic symbiosis between fungi and plant roots. The mycorrhizal fungi could increase plant growth by increasing the nutrient adsorption, particularly phosphorus [8]. They also have the effects of increasing plant resistance to drought, controlling root infection by pathogens, producing the growth stimulating compounds, and stimulating the activities of some advantageous organisms to improve soil structure and aggregation as well as mineral nutrient distribution [9].

Nitrogen -fixing bacteria (Azotobacter) are known to supply additional nitrogen in an eco-friendly manner. Azotobacter has been found to synthesize plant growth-promoting substances, such as auxins, gibberellins, cytokinins and some antibiotic metabolites. This bacteria can impact plant growth indirectly by expanding the population of beneficial microorganisms in the rhizosphere [10].

This study aimed to assess the impacts of the inoculation of bio-fertilizers ( $A$. chroococcum, G. mosseae, and A. chroococcum + G. mosseae) and chemical fertilizer ( $50 \%$ and $100 \%$ of recommended dose) under $50 \%$ and $20 \%$ of soil field capacity on proline content and the activities of antioxidant enzymes (catalase and peroxidase) in wheat Triticum aestivum L.

\section{Materials and methods Soil collection}

Four soil samples were collected from wheat and barley fields suffering from drought in Al Ramadi city, West Iraq, during March 2018. Samples were collected in pored polyethylene bags from a depth of $0-30 \mathrm{~cm}$ below the soil surface, i.e. from the Rhizosphere of roots, and stored at room temperature to be used for the isolation of arbuscular mycorrhizal fungi (AMF) and A. chroococcum. 


\section{Isolation and identification of AM fungi from root -soil texture}

The AM fungi spores were isolated by utilizing the wet sieving and decanting procedure [11]. The procedure used was as in the following:

- The root-soil blend was thoroughly mixed with a $30 \mathrm{sec}$ glass bar.

- The mixture was left for $10 \mathrm{sec}$ to settle heavier particles and organic material. The remaining soil-root-hyphae-spores suspension was slowly poured through a set of three sieves (pores of 85,65 , and $25 \mu$, respectively).

- The extract was washed away from the sieves to petri dishes of $10 \mathrm{~cm}$ diameter.

- A dissecting microscope was used to visualize the spores, aggregates, and sporocarps which were collected by a pipette.

The fresh spores were used for the identification, based on morphology of spores, spore bearing structures, and sporocarps [12].

\section{Isolation of Azotobacter chroococcum from Soil}

Azotobacter chroococcum was isolated from soil samples following a previously described method [13].

- Gradient dilutions of soil solution (3-10, 5-10) were prepared for each sample.

- One $\mathrm{ml}$ from each dilution was set in $250 \mathrm{ml}$ flask containing $50 \mathrm{ml}$ of $\mathrm{N}$ - free Jensen's broth and incubated at $30^{\circ} \mathrm{C}$ for 2-5days.

- The flasks were examined for a film of surface growth formation. A wet mount, preferably of the surface film, was prepared and observed with compound microscope.

- Plates of $\mathrm{N}$ - free Jensen's agar were streaked and incubated at $30^{\circ} \mathrm{C}$ for $1-2$ days.

- The plates were examined for the presence of colonies, which were wet mounted and examined for Gram staining.

- The pure colonies were examined and used as inoculums for a slant of $\mathrm{N}$ - free Jensen's agar medium.

- All the isolates of Azotobacter sp. were subjected to biochemical characterizations, which included Gram stain reaction and growth on $\mathrm{N}$ - free medium containing $1 \%$ sucrose, manifold, and rhamnose as a sole carbon source.

\section{Field experiment}

The experiment was conducted during 2018-2019 in the Biology Department's research field, College of Science, University of Baghdad, Baghdad, Iraq. The chemical and physical characteristics of field soil were measured in the laboratory of Soil Department, College of Agriculture, University of Baghdad (Table 1). Field plots (48 plots, $1 \times 2 \mathrm{~m}$ ) were prepared in the field that was equipped with a greenhouse. To prevent possible horizontal movement of irrigated water and inoculants, the plots were separated from each other by a plastic sheet inserted vertically into the soil to a depth of $35 \mathrm{~cm}$. Cultivar grains of wheat ( IPA 99) were manually sown in their respective plots in rows of two meters each with a distance of $20 \mathrm{~cm}$ between them ( 3 rows per plot) and a seeding rate of $10 \mathrm{~g}$ per row $\left(150 \mathrm{~kg} / \mathrm{ha}^{-1}\right)$. The plots were treated with bio-fertilizers consisted of G. mosseae, A. chroococcum, separately or in combination. Chemical fertilizers (Chf) used were urea at $140 \mathrm{~kg} / \mathrm{ha}^{-1}$ and super phosphate $\left(\mathrm{P}_{2} \mathrm{O}_{5}\right)$ at $250 \mathrm{~kg} / \mathrm{ha}^{-1}$. Before seed planting, the whole amount of phosphorus fertilizer was added, while urea was split into two equal quantities. The first amount (50\%) was added before planting, i.e. during the preparation of the soil, whereas the second one (100\%) was added 40 days after sowing (during the early tillering stage). The seeds of Triticum aestivum L. cultivar (IPA 99) were sowed in 28 November 2018. Water stress was applied to the soilfield capacity by irrigating the plots and then withholding the next irrigation until soil moisture reached $50 \%$ and $20 \%$ of soil field capacity. Over the course of the analysis, all weeds were uprooted by hand-weeding. The soil humidity of the plots was measured using a weight basis method [14]. 


\section{Results}

\section{Physical and chemical properties of soil}

The results of soil analysis revealed that the soil texture was loam with $\mathrm{EC}$ of 1.1 and $\mathrm{pH}$ of 7.4. Concentrations of available N, P, and $\mathrm{K}$ were $14.58,24.36$, and $375.16 \mathrm{mg} . \mathrm{kg}^{-1}$, respectively ( Table 1).

Table 1- Some physical and chemical properties of soil used in the experiment.

\begin{tabular}{|c|c|c|c|c|c|c|c|c|c|}
\hline $\begin{array}{c}\text { Sand } \\
\text { (g/ / kg soil) }\end{array}$ & $\begin{array}{c}\text { Silt } \\
\text { (g/kg soil) }\end{array}$ & $\begin{array}{c}\text { Clay } \\
\text { (g/kg soil) }\end{array}$ & $\begin{array}{c}\text { Soil } \\
\text { texture }\end{array}$ & \multicolumn{2}{|c|}{$\begin{array}{c}\text { Field } \\
\text { capacity }\end{array}$} & pH & $\begin{array}{c}\text { EC } \\
\text { ds/ } \\
\mathbf{m}\end{array}$ & \multicolumn{3}{|c|}{$\begin{array}{c}|c| \\
\text { Available nutrients } \\
\text { mg. kg-1 }\end{array}$} \\
\hline 320 & 430 & 250 & Loam & 31 & 7.4 & 1.1 & 14. & 24.36 & 375.16 \\
\hline
\end{tabular}

\section{Proline content in wheat treated with bio- and chemical fertilizers}

The results presented in table 2 reveal that proline content was essentially increased by the stress of water deficit. The highest mean level of proline $(4.62 \mu \mathrm{mole} / \mathrm{g})$ was recorded at $20 \%$ water deficit, while the lowest $(3.56 \mu$ mole/g) was at $50 \%$ water deficit.

Besides, according to bio-fertilizer treatment, the high mean level of proline (4.78 $\mu$ mole/g) was recorded in the control group, while the lowest $(3.78 \mu$ mole $/ g)$ was recorded by the treatment with Azoto +AMF. According to chemical fertilizer treatment, the highest mean $(4.18 \mu \mathrm{mole} / \mathrm{g}) \mathrm{was}$ at $50 \%$ chemical fertilization, while the lowest was $(4.00 \mu \mathrm{mole} / \mathrm{g})$ at 100 $\%$ chemical fertilization.

In addition, the interaction between chemical fertilization and water deficit significantly affected proline content in the plant; the highest mean was $4.72 \mu \mathrm{mole} / \mathrm{g}$ at $50 \%$ chemical fertilization with $20 \%$ water deficit, while the lowest was $3.49 \mu$ mole/g at $100 \%$ chemical fertilization with $50 \%$ water deficit.

Also, the interaction between chemical and bio-fertilization significantly affected proline content; the highest value was $4.86 \mu \mathrm{mole} / \mathrm{g}$ at $50 \%$ chemical fertilization, while the lowest was $3.70 \mu \mathrm{mole} / \mathrm{g}$ at Azoto +AMF with $100 \%$ chemical fertilization. Moreover, the relationship between water deficit and bio-fertilizers significantly affected the results; the highest proline level was $5.72 \mu$ mole/g at $20 \%$ water deficit, but the lowest was $3.40 \mu \mathrm{mole} / \mathrm{g}$ at Azoto + AMF with $50 \%$ water deficit.

Moreover, the triple interaction among chemical fertilizers, water deficit, and biofertilizers significantly affected proline content. Maximum proline content $(5.84 \mu \mathrm{mole} / \mathrm{g})$ was recorded at $50 \%$ chemical fertilizers with $20 \%$ water deficit, while minimum proline content $(3.35 \mu \mathrm{mole} / \mathrm{g})$ was recorded by Azoto+AMF with $100 \%$ chemical fertilizers and $50 \%$ water deficit.

Table 2-Effects of chemical fertilizers, water availability, and AMF and AZOTO inoculation on proline content $(\mu$ mole $/ g)$ in wheat

\begin{tabular}{|c|c|c|c|c|c|c|c|}
\hline \multirow[b]{2}{*}{ Chf \% } & \multirow{2}{*}{$\begin{array}{c}(\mathrm{H}): \\
\text { Water \% }\end{array}$} & \multicolumn{4}{|c|}{ Biological treatments } & \multirow{2}{*}{\multicolumn{2}{|c|}{$(\operatorname{chf} \times H)$}} \\
\hline & & (AMF) & (Azoto) & $\begin{array}{c}\text { (Azoto + } \\
\text { AMF) }\end{array}$ & Control & & \\
\hline \multirow{2}{*}{50} & 20 & 4.44 & 4.34 & 4.28 & 5.84 & & 4.72 \\
\hline & 50 & 3.66 & 3.57 & 3.45 & 3.88 & & 3.64 \\
\hline \multirow{2}{*}{100} & 20 & 4.24 & 4.17 & 4.05 & 5.60 & & 4.51 \\
\hline & 50 & 3.42 & 3.41 & 3.35 & 3.79 & & 3.49 \\
\hline LSD & -- & \multicolumn{4}{|c|}{ LSD $(\operatorname{chfHT})=0.492$} & LSD & $\mathrm{fH})=0.451$ \\
\hline \multicolumn{2}{|c|}{$(\operatorname{chf} \times \mathrm{T})$} & \multicolumn{4}{|c|}{ LSD $(\operatorname{chfT})=0.801$} & \multicolumn{2}{|c|}{ Mean of (chf) } \\
\hline \multicolumn{2}{|c|}{$(\mathrm{chf}): 50$} & 4.05 & 3.95 & 3.86 & 4.86 & 4.18 & \multirow{2}{*}{$\begin{array}{c}\text { LSD (chf) }= \\
0.173\end{array}$} \\
\hline \multicolumn{2}{|c|}{ (chf): 100} & 3.83 & 3.79 & 3.70 & 4.69 & 4.00 & \\
\hline
\end{tabular}




\begin{tabular}{|c|c|c|c|c|c|}
\hline$(\mathrm{H} \mathrm{x} \mathrm{T})$ & & & & & Mean of $(\mathrm{H})$ \\
\hline$(\mathrm{H}): 20$ & 4.34 & 4.25 & 4.16 & 5.72 & 4.62 \\
\hline (H): 50 & 3.54 & 3.49 & 3.40 & 3.84 & 3.56 \\
\hline LSD & \multicolumn{4}{|c|}{$\operatorname{LSD}(\mathrm{HT})=0.330$} & $\operatorname{LSD}(\mathrm{H})=0.173$ \\
\hline Mean of $(\mathrm{T})$ & 3.94 & 3.87 & 3.78 & 4.78 & $\operatorname{LSD}(\mathrm{T})=0.246$ \\
\hline
\end{tabular}

Chf: chemical fertilizer, $\mathrm{H}$ : water deficit , T: treatment

Impacts of bio- and chemical fertilizers on catalase and peroxidase activities on leaves of wheat under drought conditions

\section{a- Catalase enzyme activity}

The results introduced in Table 3 demonstrate that the mean value of catalase activity was greatly increased by the stress of water deficit . The highest catalase activity $(93.69 \mathrm{unit} / \mathrm{ml})$ was recorded at $20 \%$ water deficit, while the lowest $(87.64$ unit $/ \mathrm{ml})$ was at $50 \%$ water deficit.

Besides, based on bio-fertilizer treatment, the high mean catalase activity $(92.99 \mathrm{unit} / \mathrm{ml})$ was recorded in the control, while the lowest $(89.18 \mathrm{unit} / \mathrm{ml})$ was recorded at Azoto +AMF. Based on chemical fertilizer treatment, the highest mean was $91.56 \mathrm{unit} / \mathrm{ml}$ at $50 \%$ chemical fertilization, while the lowest was $89.76 \mathrm{unit} / \mathrm{ml}$ at $100 \%$ chemical fertilization.

Furthermore, the interaction between chemical fertilization and water deficit significantly affected the results; the highest mean catalase activity was $94.51 \mathrm{unit} / \mathrm{ml}$ at $50 \%$ chemical fertilization with $20 \%$ water deficit, while the lowest was 86.65 unit $/ \mathrm{ml}$ at $100 \%$ chemical fertilization with $50 \%$ water deficit.

Also, the interaction between chemical and bio-fertilization significantly affected the results; the highest value was $93.36 \mathrm{unit} / \mathrm{ml}$ at $50 \%$ chemical fertilization, while the lowest was $88.06 \mathrm{unit} / \mathrm{ml}$ at Azoto +AMF with $100 \%$ chemical fertilization. Moreover, the relationship of water deficit with bio-fertilizers significantly affected the results; the highest value was 95.47 unit $/ \mathrm{ml}$ at $20 \%$ water deficit, but the lowest was 85.89 unit $/ \mathrm{ml}$ at Azoto $+\mathrm{AMF}$ with $50 \%$ water deficit.

However, the triple interaction among chemical fertilizers, water deficit, and bio-fertilizers significantly affected catalase activity. Maximum catalase activity (95.93unit $/ \mathrm{ml}$ ) was recorded by treatment with $50 \%$ chemical fertilizers and $20 \%$ water deficit, while minimum catalase activity $(84.52$ unit $/ \mathrm{ml})$ was recorded by Azoto+AMF with $100 \%$ chemical fertilizers and $50 \%$ water deficit.

Table 3- Effects of chemical fertilizers, water availability, AMF and A. chroococcum inoculation on catalase enzyme activity ( unit / $\mathrm{ml}$ ) in the leaves of wheat.

\begin{tabular}{|c|c|c|c|c|c|c|c|}
\hline \multirow[b]{2}{*}{ Chf $\%$} & \multirow[b]{2}{*}{$\begin{array}{c}(\mathrm{H}): \\
\text { Water \% }\end{array}$} & \multicolumn{4}{|c|}{ Biological treatments } & \multirow{2}{*}{\multicolumn{2}{|c|}{$(\operatorname{chf} \times H)$}} \\
\hline & & (AMF) & (Azoto) & $\begin{array}{c}\text { (Azoto + } \\
\text { AMF) }\end{array}$ & Control & & \\
\hline \multirow{2}{*}{50} & 20 & 94.83 & 93.95 & 93.35 & 95.93 & & 4.51 \\
\hline & 50 & 88.65 & 87.77 & 87.27 & 90.80 & & 8.62 \\
\hline \multirow{2}{*}{100} & 20 & 92.69 & 92.20 & 91.60 & 95.01 & & 2.87 \\
\hline & 50 & 86.51 & 85.38 & 84.52 & 90.22 & & 6.65 \\
\hline LSD & -- & \multicolumn{4}{|c|}{ LSD $(\operatorname{chfHT})=4.607$} & LSD & $\mathrm{hfH})=1.32$ \\
\hline \multicolumn{2}{|c|}{$(\operatorname{chf} \times \mathrm{T})$} & \multicolumn{4}{|c|}{$\mathrm{LSD}(\operatorname{chfT})=3.91$} & \multicolumn{2}{|c|}{ Mean of (chf) } \\
\hline \multicolumn{2}{|c|}{ (chf): 50} & 91.74 & 90.86 & 90.31 & 93.36 & 91.56 & $\operatorname{LSD}(\mathrm{chf})=$ \\
\hline \multirow{2}{*}{\multicolumn{2}{|c|}{$\frac{(\mathrm{chf}): 100}{(\mathrm{H} \times \mathrm{T})}$}} & 89.60 & 88.79 & 88.06 & 92.61 & 89.76 & 0.214 \\
\hline & & & & & & \multicolumn{2}{|c|}{ Mean of $(\mathrm{H})$} \\
\hline \multicolumn{2}{|c|}{$(\mathrm{H}): 20$} & 93.76 & 93.07 & 92.47 & 95.47 & \multicolumn{2}{|c|}{93.69} \\
\hline \multicolumn{2}{|c|}{$(\mathrm{H}): 50$} & 87.58 & 86.57 & 85.89 & 90.51 & & 7.64 \\
\hline & & \multicolumn{4}{|c|}{$\mathrm{LSD}(\mathrm{HT})=1.291$} & LSD & $\mathrm{H})=0.214$ \\
\hline \multicolumn{2}{|c|}{ Mean of $(\mathrm{T})$} & 90.67 & 89.82 & 89.18 & 92.99 & LSD & $T)=0.303$ \\
\hline
\end{tabular}

Chf: chemical fertilizer, H: water deficit , T: treatment 


\section{b- Peroxidase enzyme activity}

Peroxidase activity in the leaves of wheat was significantly increased with the progression of water stress period in all treatments under study. The greatest peroxidase activity (118.81 unit $/ \mathrm{ml}$ ) was recorded at $20 \%$ water deficit, while the lowest $(99.79$ unit $/ \mathrm{ml})$ was at $50 \%$ water deficit (Table 4).

Besides, according to bio-fertilization treatment, the highest mean peroxidase activity (116.92 unit $/ \mathrm{ml}$ ) was recorded by the treatment of control, while the lowest $(104.43 \mathrm{unit} / \mathrm{ml})$ was at Azoto +AMF. Also, according to chemical fertilization, the highest mean (112.35 unit $/ \mathrm{ml})$ was at $50 \%$ chemical fertilization, while the lowest $(106.24 \mathrm{unit} / \mathrm{ml})$ was at $100 \%$ chemical fertilization.

Moreover, the interaction between chemical fertilization and water deficit significantly affected peroxidase activity; the highest mean (121.47 unit $/ \mathrm{ml})$ was at $50 \%$ chemical fertilization with $20 \%$ water deficit, while the lowest $(96.33$ unit $/ \mathrm{ml})$ was at $100 \%$ chemical fertilization with $50 \%$ water deficit.

Also, the interaction between chemical and bio-fertilization significantly affected the results; the highest value $(118.14 \mathrm{unit} / \mathrm{ml})$ was at $50 \%$ chemical fertilization, while the lowest (101.32 unit $/ \mathrm{ml})$ was at Azoto+AMF with $100 \%$ chemical fertilization. Moreover, the interaction of water deficit and bio-fertilizers significantly affected the results; the highest value $(126.20 \mathrm{unit} / \mathrm{ml})$ was at $20 \%$ water deficit, but the lowest $(95.11 \mathrm{unit} / \mathrm{ml})$ was at Azoto $+\mathrm{AMF}$ with $50 \%$ water deficit.

Additionally, the triple interaction between chemical fertilizers, water deficit and biofertilizers significantly affected peroxidase activity. Maximum peroxidase activity ( 126.80 unit $/ \mathrm{ml}$ ) was recorded at $50 \%$ chemical fertilizers with $20 \%$ water deficit, while minimum peroxidase activity $(90.90 \mathrm{unit} / \mathrm{ml})$ was recorded by Azoto+AMF treatment with $100 \%$ chemical fertilizers and $50 \%$ water deficit.

Table 4-Effect of chemical fertilizers levels, water availability, AMF and A. chroococcum inoculation in peroxidase enzyme activity (unit/ $\mathrm{ml}$ )

\begin{tabular}{|c|c|c|c|c|c|c|c|}
\hline \multirow[b]{2}{*}{$\mathrm{Chf} \%$} & \multirow{2}{*}{$\begin{array}{c}(\mathrm{H}): \\
\text { Water \% }\end{array}$} & \multicolumn{4}{|c|}{ Biological treatments } & \multirow{2}{*}{\multicolumn{2}{|c|}{$(\operatorname{chf} \times H)$}} \\
\hline & & (AMF) & (Azoto) & $\begin{array}{c}\text { (Azoto + } \\
\text { AMF) }\end{array}$ & Control & & \\
\hline \multirow{2}{*}{50} & 20 & 123.53 & 119.81 & 115.76 & 126.80 & \multicolumn{2}{|c|}{121.47} \\
\hline & 50 & 103.81 & 100.38 & 99.31 & 109.48 & \multicolumn{2}{|c|}{103.24} \\
\hline \multirow{2}{*}{100} & 20 & 114.66 & 112.61 & 111.74 & 125.61 & \multicolumn{2}{|c|}{116.16} \\
\hline & 50 & 95.78 & 92.83 & 90.90 & 105.80 & \multirow{2}{*}{\multicolumn{2}{|c|}{$\begin{array}{c}96.33 \\
\mathrm{LSD}(\operatorname{chfH})=4.27\end{array}$}} \\
\hline LSD & -- & \multicolumn{4}{|c|}{ LSD $(\operatorname{chfHT})=6.599$} & & \\
\hline \multirow{2}{*}{\multicolumn{2}{|c|}{$\begin{array}{l}(\operatorname{chf} \times \mathrm{T}) \\
(\operatorname{chf}): 50\end{array}$}} & \multicolumn{4}{|c|}{$\mathrm{LSD}(\operatorname{chfT})=5.23$} & \multicolumn{2}{|c|}{ Mean of( chf) } \\
\hline & & 113.67 & 110.09 & 107.53 & 118.14 & 112.35 & LSD \\
\hline \multicolumn{2}{|c|}{ (chf): 100} & 105.22 & 102.72 & 101.32 & 115.70 & 106.24 & $\begin{array}{l}\text { (cht) }= \\
0.565\end{array}$ \\
\hline \multicolumn{2}{|c|}{$(\mathrm{H} \times \mathrm{T})$} & & & & & \multicolumn{2}{|c|}{ Mean of H } \\
\hline \multicolumn{2}{|c|}{$(\mathrm{H}): 20$} & 119.09 & 116.21 & 113.75 & 126.20 & \multicolumn{2}{|c|}{118.81} \\
\hline \multirow{2}{*}{\multicolumn{2}{|c|}{$\frac{(\mathrm{H}): 50}{\text { LSD }}$}} & 99.79 & 96.61 & 95.11 & 107.64 & & \\
\hline & & \multicolumn{4}{|c|}{ LSD $(\mathrm{HT})=5.36$} & \multirow{2}{*}{\multicolumn{2}{|c|}{$\begin{array}{l}\text { LSD }(\mathrm{H})=0.565 \\
\mathrm{LSD}(\mathrm{T})=0.799\end{array}$}} \\
\hline \multicolumn{2}{|c|}{ Mean of(T) } & 109.44 & 106.41 & 104.43 & 116.92 & & \\
\hline \multicolumn{8}{|c|}{$(\mathrm{P}<0.05)$} \\
\hline
\end{tabular}

Chf: chemical fertilizer, H: water deficit , T: treatment

\section{Mycorrhizal colonization in roots}

The results in Table 5 show that the percentage of mycorrhiza colonization decreased significantly when the level of chemical fertilizer was increased from $50 \%$ to $100 \%$ for all treatments. The highest value was recorded upon adding $50 \%$ of the chemical fertilizer and all treatments. The treatments of G. mosseae and G. mosseae + Azotobacter with $20 \%$ water deficit and 50\% chemical fertilizer gave the highest value (90\%) as shown in Figure 1. 
Table 5-Effects of bio-fertilizers and chemical fertilizers on the percentage of mycorrhizal colonization in wheat roots

\begin{tabular}{|c|c|c|}
\hline Treatments & Chemical fertilizer & Mycorrhizal infection \\
\hline G. + Azoto $+50 \%$ water stress & $100 \%$ & $20 \%$ \\
\hline G. mosseae $+20 \%$ water stress & $100 \%$ & $25 \%$ \\
\hline G. + Azoto $+20 \%$ water stress & $100 \%$ & $20 \%$ \\
\hline G. mosseae $+50 \%$ water stress & $100 \%$ & $90 \%$ \\
\hline G. mosseae $+20 \%$ water stress & $50 \%$ & $70 \%$ \\
\hline G. mosseae $+50 \%$ water stress & $50 \%$ & $80 \%$ \\
\hline G. + Azoto $+50 \%$ water stress & $50 \%$ & $90 \%$ \\
\hline G. + Azoto $+20 \%$ water stress & $50 \%$ & $20 \%$ \\
\hline
\end{tabular}

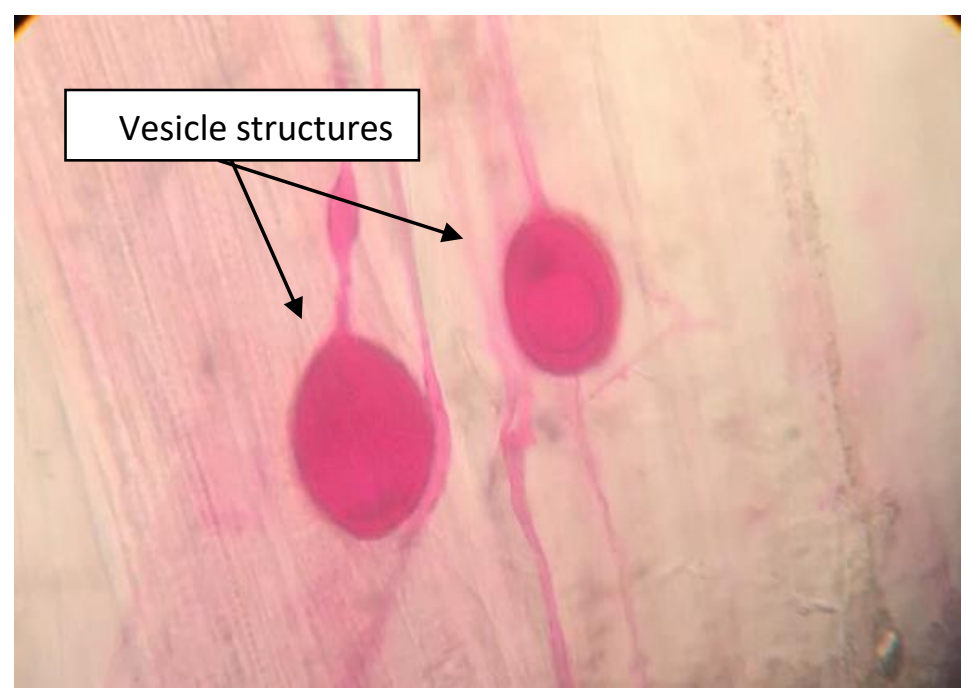

Figure 1-Mycorrhiza vesicles at treatment with G. mosseae + $20 \%$ water stress at $50 \%$ chemical fertilizer (40X) 


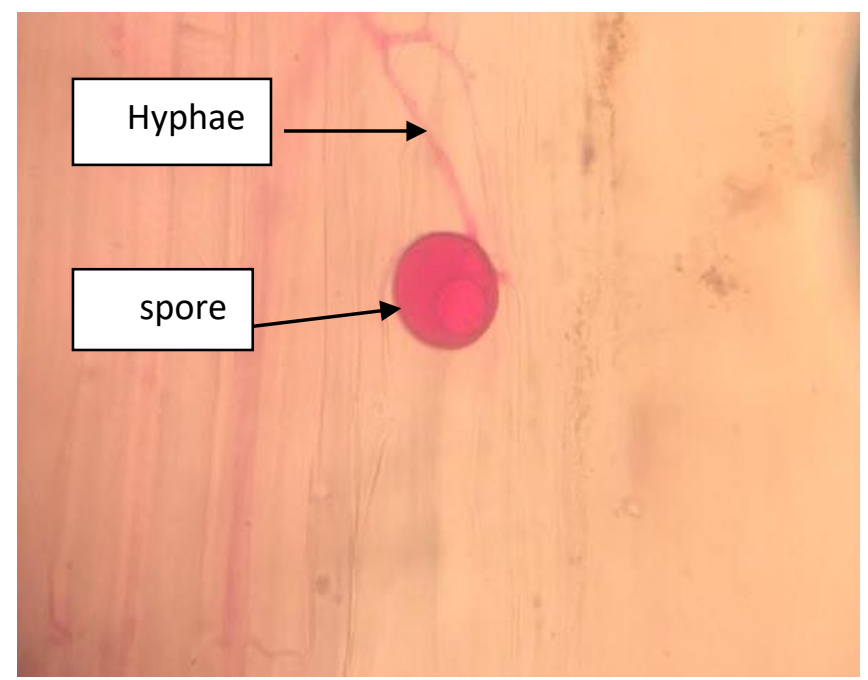

Figure 2-Mycorrhiza vesicles at treatment with G.mosseae+A.chroococcum $+50 \%$ water stress at $50 \%$ chemical fertilizer (40X)

\section{Discussion}

Rhizosphere is a wealthy habitat of micro-organisms that was explored in order to obtain the potential plant growth- promoting rhizo-bacteria (PGPR), that can be useful in the development of bio-inoculants to enhance crop growth and yield. Bio-fertilizer inoculation improved yield and yield component of wheat plant. In this study, one genus of each of free living bacteria and fungi were isolated, purified, and identified to study their effects synergistically with chemical fertilizers on wheat plant.

The results of the field experiment showed that the lowest values of proline content and antioxidant enzymes' activities in leaves of wheat were recorded in response to the treatment with Azoto+AMF with $100 \%$ chemical fertilization and $50 \%$ water deficit. These decreases indicate the potential action of bio-fertilizers. The results illustrated the accumulation of proline under drought conditions. It is believed that proline plays a major role in maintaining membrane stability and subsequently reducing the leakage of nutrients and the loss of water in cells grown under drought stress. These results agree with those of [15] who reported the decrease of proline content in leaves of wheat inoculated with bio-fertilizers under drought conditions.

The effects of $A$. chroococcum were described in relation to nitrogen fixation and uptake from the soil after converting it into amino acids and then into protein compounds derived from the plant. This improves the growth of the plant and increases its weight as a result of encouraging the absorption of phosphorus to form a dense root mass that help absorb water and nutrients [16] .In addition, symbiosis of AMF with plant roots was reported to be accommodating in tolerating and overcoming episodes of water stress in various plant species [17], including wheat [18].

Antioxidant activity upon stress conditions could prevent oxidative damage caused by reactive oxygen species. Also, the generation of catalase increases at water stress conditions. These results agree with those of [19] who revealed that, under drought stress, the expression levels of CAT in seedlings of the bio-fertilizers were lower than those of control treatment.

The results also showed superior peroxidase activity under control conditions as compared with bio-fertilizer treatment which decreased the peroxidase activity. These results agree with those of $[15,20]$ who mentioned lower peroxidase and catalase activities in wheat plant inoculated with a bio-fertilizer under drought condition.

The reason that the percentage of mycorrhizal infection increased significantly is that, under phosphorus deficiency conditions, the amount of phospholipids in the root cell 
membranes decreases, leading to increased permeability of these membranes. This leads to increased root secretion of reduced sugars and amino acids, thus increasing the proportion of infected roots. Under phosphorus availability conditions, the permeability of the membranes of the root cells is reduced due to the increase in their phospholipids and the decreases in the amounts of sugars and amino acids, leading to a decrease of infected roots [21]. This negative effect of high nitrogen and phosphate-content fertilizers on the percentage of mycorrhizal infection is in agreement with that described by many researchers [22,23].

In conclusion, the use of bio-fertilizers with chemical fertilizers improves the yield and yield components and decreases proline content and antioxidant enzymes' activities of wheat plant under drought conditions.

\section{References}

[1] Dennis, B.E. and Bruening, W.P. 2000. Potential of early maturing soybean cultivars in late plantings. Agron.J., 92:532-537.

[2] Lambers, H., Chapim, F., and Pons, T. 2008.Physiological ecology.2nd ed. Berlin: Springer.

[3] Sultan, M.A., Hui, L., Yang, L.J. and Xian, Z.H. 2012. Assessment of drought tolerance of some Triticum L. Species through physiological Indices. Czech J. Genet .Plant Breed. 48(4): 178-184.

[4] Abdollah, M. , Davood, H. , Mahyar, R., and Saeed, M. 2011. Effect of Drought Stress on Antioxidant Enzymes Activity of Some Chickpea Cultivars. American-Eurasian J. Agric. \& Environ. Sci., 11 (6): 782-785.

[5] Demiral, T. and Turkan, I. 2005. Comparative lipid peroxidation, antioxidant defense systems and proline content in roots of two rice cultivars differing in salt tolerance. Environ. Exp. Bot., 53: 247-257.

[6] Srivalli, B, Sharma, G. and Khanna-Chopra, R. 2003. Antioxidative defense system in upland rice cultivar subjected to increasing intensity of water stress followed by recovery. Physiologia Plantarum, 119: 503-512.

[7] Jung, S. 2004. Variation in antioxidant metabolism of young and mature leaves of Arabidopsis thaliana subjected to drought. Plant Science relations of wheat. Botanical Bulletin Academia Sinica, 41:35-39.

[8] Azcon, R., Barea, J.M. and Hayman, D.S. 1979. Utilization of rock phosphate in alkaline soils by plant inoculated with mycorrhizal fungi and phosphate solubilizing bacteria. Soil Biol. Biochem. 8: $135-138$.

[9] Ramadhani, R., Damanhuri, S. and Basuki, N. 2015. A study of mycorrhizal inoculation on some Genotypes of wheat (Triticum aestivum L.). IOSR Journal of Agriculture and Veterinary Science (IOSR-JAVS), 8(2): 42-49.

[10] Jaga, P.K., Sharma, S. and Patel, Y. 2017. Response of wheat (Triticum aestivum) to Azotobacter inoculation and nitrogen in soils of vidisha, madhya pradesh. Annals of plant and soil research, 19(1):42-45.

[11]Gerdemann, J. W. and Nicolson ,T. H. 1963. Spores of mycorrhizal endogen species extracted from soil by wet-sieving and decanting. Trans.Br. Mycol. Soc., 46: 235 - 239.

[12]Powell , C. L. and Bagyaraj, D. J. 2000. VA- mycirrhiza . CRD. Press. Inc., pp. 234.

[13] Ahmed, F., Iqbal, A. and Mohd, K. 2005. Indole acetic acid production by the indigenous isolates of Azotobacter and Fluorescent Pseudomonas in the presence and absence of tryptophan . Turk. J. Biol., 29: 29- 34.

[14] Standards Association of Australia. 1977. Determination of the field dry density of a soilsand replacement method using a sand-cone pouring apparatus. In Australian standard methods of testing soil for engineering purposes, Part E-Soil compaction and density tests. (Standards Association of Australia: Sydney).

[15] Jawad, M.M. 2014. The effect of bio-fertilizers on drought tolerance of two wheat (Triticum aestivum L.) cultivars under field conditions. Thesis, Department of Biology, College of Science, Baghdad University, Iraq.

[16] Khan, I., Anwar, M. and Aquil, A. .2010. Effect of nitrogen fixing bacteria on plant growth and yield of Brassica Juncea. Journal of philology, 2 (9): 25-27. 
[17]Chitarra, W., Biancaelena, M., Giorgio, G., Emilio, G. and Raffaella, B. 2016. Arbuscular mycorrhizal symbiosis-mediated tomato tolerance to drought. Plant Signaling \& Behavior, 11(7).

[18] Moucheshi, A. , Heidari, B. and Assad, M. 2012. Alleviation of drought stress effects on wheat using arbuscular mycorrhizal symbiosis. International Journal of Agri. Science 2(1): 3547.

[19]Li , Y., Shi, H., Zhang, H. and Chen, S. 2019. Amelioration of drought effects in wheat and cucumber by the combined application of super absorbent polymer and potential bio-fertilizer. PeerJ., doi: 10.7717/peerj.6073.

[20] Razieh, K., Raouf, S. and Jalal, J. 2016. Antioxidant status and physiological responses of wheat (Triticum aestivum L.) to cycocel application and bio fertilizers under water limitation condition. Journal of Plant Interactions, 11(1): 1-16.

[21] Habte, M. and Osorio, N.W. 2001. Arbuscular mycorrhizas: Producing and applying arbuscular mycorrhizal inoculum. University of Hawaii, Honolulu,pp. 47.

[22] Bashir, A. Y. 2003. The interaction between mycorrhizae, Azotobacter and Azospirillum bacteria and their effect in growth and yield of wheat. Thesis submitted to college of Agriculture , university of Baghdad.

[23] Suhel, F. M. 2008. The effect of bio and chemical fertilizers on growth and grain yield of wheat plants(Triticum aestevium) with and without pesticide application. Diala J., 31. 